\title{
EU agencies: does the Meroni Doctrine make sense?
}

\author{
Merijn Chamon*
}

Two decades ago the process of agencification of the EU administration was initiated and has gained momentum ever since. Today there are about 30 agencies scattered across the $E U$, active in different policy fields and entrusted with different tasks. In a first part this article looks at the history and rationale of agency creation and at the political framework in which EU agencies operate. In a second part, building on the definition and classification of agencies by Griller and Orator, a closer look will be taken at the institutional position of the EU agencies. Because the creation of agencies was neither excluded nor foreseen in the Founding Treaties most authors search for clarification in the 1958 Meroni ruling of the CJEU. This article challenges this line of reasoning by identifying a number of problems. Furthermore this article also challenges the way in which a number of authors deduct the principle of institutional balance from the Meroni ruling, applying it to the functioning of agencies, thereby misconstruing the Court's original concern which it sought to express through this principle. In a last part the article links this legal discussion to the political discussions on the future framework for the agencies, identifying a critical role for the Commission in supporting the above mentioned dominant legal reasoning.

Keywords: EU Agencies; Delegated powers; Meroni; institutional balance; bureaucratic competition

\section{§1. INTRODUCTION}

EU Agencies are a relatively new yet distinctive feature of the Union's administrative system. Paradoxically, this distinctiveness does not result so much from their visibility, as from the sheer number of agencies that has been established and the obscurity in which most of them are shrouded. ${ }^{1}$ In the contemporary academic debate, a lot of authors refer to the Meroni judgment when discussing the delegation of powers to these agencies. This article challenges the way in which the Meroni judgment is being interpreted in the current debate on agencies, by trying to re-construct the original meaning of the judgment. Before tackling this issue however, the history, rationale and politics behind the establishment of agencies is explored in

\footnotetext{
*Assistant, European Institute, Ghent University. I would like to thank Prof. Van Elsuwege and especially dr. Kirstyn Inglis for their valuable comments and suggestions. Any errors or inaccuracies remain solely mine. This article was completed in April 2010.

${ }^{1}$ Today there are around 30 EU agencies established and more are in the pipeline.
} 
a brief general overview. The focus then turns to the legal framework itself. As is explained, agencies are not foreseen in primary law nor is there any case law of the Court of Justice of the European Union (CJEU) specifically dealing with the institutional position of the agencies.

As noted, it is this hiatus that numerous authors but also the European Commission have tried to remedy by referring to the Meroni judgment. In its ruling, dating from 1958, the CJEU ruled out the possibility for the High Authority to delegate discretionary powers to bodies established under private law. ${ }^{2}$ The main thrust of this article is the twofold assertion that the facts and context of the Meroni case stand in the way of a simple transposition of the ruling to the functioning of the current day agencies and that a mis-reading of the Court's judgment is at the root of much of the contemporary literature on agencies. Lastly, the challenges of agencification were also noticed by the Union institutions, which are currently discussing a framework for the agencies, after the Commission's withdrawal of its initial proposal for a draft interinstitutional agreement for such a framework. Therefore, in a third and final part, the proposal, which brought together the politics of agencification identified in the general overview and the criticized contemporary reading of the Meroni judgment in the second part, is scrutinized, as well as the possible consequences of a re-read Meroni judgment for the debate between the institutions.

\section{§2. AGENCIES: A GENERAL OVERVIEW}

\section{A. DEFINING AGENCIES}

To this day there is no official definition of 'agency' as established by EU legislation. In its 2002 Communication on the operating framework for regulatory agencies, the Commission notes that the various agencies have certain formal characteristics in common: they were all created by regulation, have legal personality and have a certain degree of organisational and financial autonomy. ${ }^{3}$ In its draft interinstitutional agreement on the operating framework for

\footnotetext{
${ }^{2}$ Case 9/56 Meroni \& Co, Industrie Metallurgiche SpA v. High Authority [1958] ECR 133.

${ }^{3}$ Communication from the Commission, The operating framework for the European Regulatory Agencies, COM (2002) 718 final, p. 3.
} 
the European regulatory agencies, the Commission failed further to develop this embryonic definition and defined the regulatory agency as, 'any autonomous legal entity set up by the legislative authority in order to help regulate a particular sector at European level and help implement a Community policy. ${ }^{4}$ This said, the Commission does not explain why the socalled executive agencies should be excluded from this definition and this strengthens the impression that its generic definition lacks clarity and precision. The definition that is used here is that proposed by Griller and Orator who define agencies as relatively independent, permanent bodies with legal personality, emanating from secondary Union law and charged with specific tasks. ${ }^{5}$

\section{B. GROWTH AND RATIONALE OF AGENCIES}

The number of EU agencies has grown steadily over the years in a number of consecutive waves. The first wave occurred in the 1970s and resulted in the establishment of two agencies. The agencies of the first wave have only limited powers. More important are the second and third waves, of the 1990s and 2000s respectively: the second wave produced 11 new agencies; the third wave added another 16 and, as mentioned, is not yet complete. ${ }^{6}$ Although the use of agencies dates back to the 1970s, only in the 1990s did the Community, and later the Union, start to rely more heavily on them to carry out certain specific administrative tasks. What is more, it was only with the second wave, which substantially increased the number of agencies, that the academic debate on these new institutions was sparked.

\footnotetext{
${ }^{4}$ Draft Interinstitutional Agreement on the operating framework for the European regulatory agencies, COM (2005) 59 final, p. 6.

${ }^{5}$ Griller and Orator, 'Everything under control? The "way forward" for European agencies in the footsteps of the Meroni Doctrine', 35 European Law Review 1 (2010), p. 7.

${ }^{6}$ These include the agencies under the former second and third pillar, but not the 'executive' agencies under the former first pillar which, due to their non-permanent nature, fall outside the definition and are therefore excluded.
} 
Since the 1990s the body of academic literature on European agencies has grown steadily and the many different aspects of this institutional phenomenon explored. For one, the rationale behind this institutional development is debated quite extensively. The popularity of the agency-instrument has been explained by referring to the numerous benefits or possibilities it unlocks for policymakers. Some of these are general in nature, they apply to any level of government, be it regional, national or supranational and some of these are especially relevant for the European level. When these benefits are discussed, a distinction can also be made between the 'technocratic' and 'political' reasons for agency creation. The latter are potent elucidators for the political game behind the creation of these agencies. Often cited 'technocratic' reasons are: facilitating the use of independent scientific experts, enhancing the credibility of long term policy commitments, isolating decision-making from politics. ${ }^{7}$ In essence the technocratic rationale of agencies lies in the independence of their technical and/or scientific (risk) assessments. This has been recognized by the Commission as well who describes that independence as the real raison d'être of agencies. ${ }^{8}$ Specific to or highly relevant for the agencies of the EU is that they may foster administrative integration, ${ }^{9}$ which would lead to a uniform application of common rules. ${ }^{10}$ They enable a discrete, almost invisible, deepening of political integration, ${ }^{11}$ yet also provide a certain policy area with more transparency and relieve overburdened institutions, which can then focus on their core responsibilities. $^{12}$

\footnotetext{
${ }^{7}$ Thatcher, 'The Third Force? Independent Regulatory Agencies and Elected Politicians in Europe', 18 Governance 3 (2005), p. 349.

${ }^{8}$ Communication from the Commission, The operating framework for the European Regulatory Agencies, COM (2002) 718 final, p. 5.

${ }^{9}$ Kreher, 'Agencies in the European Community - a step towards administrative integration in Europe', 4 Journal of European Public Policy 2 (1997), p. 238-241.

${ }^{10}$ Dehousse, 'Regulation by networks in the European Community: the role of European agencies', 4 Journal of European Public Policy 2 (1997), p. 246-261.

${ }^{11}$ Shapiro, 'The Problems of Independent Agencies in the United States and the European Union', 4 Journal of European Public Policy 2 (1997), p. 281-282.

${ }^{12}$ J. Trondal, An Emergent European Executive Order (Oxford University Press, Oxford 2010), p. 148.
} 
Vos also mentions potential pitfalls associated with the use of agencies. ${ }^{13}$ These are political and legal in nature. They may be summarized as the requirements of good governance and related to this are the legal challenges that the agency model entails. The powers vested in agencies are powers transferred to them from other institutions or governmental levels. In an EU context this means that, according to Vos, one should be wary about the effects of this delegation of power on the institutional balance. Furthermore, a legal base for this delegation is needed and the constitutional guarantees to which the exercise of the transferred powers was subject, prior to delegation, must be upheld.

\section{A CLASSIFICATION}

Every author contributing to the topic also has his or her own classification scheme of agencies. Although some of the schemes follow the same logic, the end results are never the same: different terminology is used and different aspects highlighted. This should not come as too big a surprise, for even the Commission has difficulties in classifying the agencies: a confusing and contradictory terminology is apparent in its communications. First, the Commission makes a distinction between the executive and regulatory agencies, ${ }^{14}$ then it differentiates in that second category between decision-making agencies and executive agencies. ${ }^{15}$ The heterogeneity in classifications reflects the diversity and heterogeneity of the agencies themselves, some of which may have similar powers and tasks but none of which are organized or function in the same way. In this contribution, the instrumental classification by Griller and Orator is borrowed. ${ }^{16}$ Instead of following a structural, temporal or functional

\footnotetext{
${ }^{13}$ Vos, 'Agencies and the European Union', in L. Verhey \& T. Zwart (eds.) Agencies in European and comparative perspective, (Intersentia, Antwerp 2003), p. 115-116.

${ }^{14}$ Communication from the Commission, The operating framework for the European Regulatory Agencies, COM (2002) 718 final, p. 3.

${ }^{15}$ Ibid., 8 .

${ }^{16}$ Griller \& Orator, ,35 European Law Review 1 (2010), p. 12-14.
} 
approach, they look at the intensity of prerogatives entrusted to the agencies. This approach results in four types of regulatory agencies: 'ordinary' agencies without decision-making powers, if decisions need to be taken this is done by the Commission; ${ }^{17}$ 'pre-decision-making' agencies, enjoying a considerable influence over the adoption of the final decision, which is again taken by the Commission. ${ }^{18}$ Concerning these agencies it is important to note that while the formal decision is taken by the Commission, the actual decision generally lies in the hands of the agencies.

The third type of agency is the genuine decision-making agency, having the capacity to enact legal instruments binding upon third parties. ${ }^{19}$ The major difference compared to the preceding category is that the de iure situation is being aligned to the de facto reality. Agencies of the third type do not require the rubberstamp of the Commission, unlike the agencies of the second type, but it is important to realize that even the latter hold considerable power, since the Commission generally lacks the expertise to assess their advice properly. ${ }^{20}$

\footnotetext{
${ }^{17}$ The follow agencies may be categorized as ordinary agencies: The European Centre for the Development of Vocational Training (Cedefop), the European Foundation for the Improvement of Living and Working Conditions (EUROFOUND), the European Environment Agency (EEA), the European Training Foundation (ETF), the European Monitoring Centre for Drugs and Drugs Addiction (CMDDA), the European Agency for Safety and Health at Work (EU-OSHA), the Translation Centre for the Bodies of the European Union (CdT), the European Union Agency for Fundamental Rights (FRA), the European Union Institute for Security Studies (ISS), the European Union Satellite Centre (EUSC), the European Police College (CEPOL), the European Network and Information Security Agency (ENISA), the European Agency for the Management of Operational Cooperation at the External Borders (FRONTEX), the European Defence Agency (EDA), the Community Fisheries Control Agency (CFCA), the European GNSS Supervisory Authority (GSA), the European Institute for Gender Equality (EIGE), the European Police Office (EUROPOL) and the Office of the Body of European Regulators for Electronic Communications (BEREC-Office).

${ }^{18}$ The pre-decisionmaking agencies are: the European Medicines Agency (EMEA), the European Food Safety Agency (EFSA), the European Union's Judicial Cooperation Unit (EUROJUST), the European Maritime Safety Agency (EMSA), the European Centre for Disease Control (ECDC), the European Railway Agency (ERA) and the European Chemicals Agency (ECHA).

${ }_{19}$ The decision-making agencies are: the Office for Harmonisation of the Internal Market (OHIM), the Community Plant Variety Office (CPVO), the European Aviation Safety Agency (EASA), the Agency for the Cooperation of Energy Regulators (ACER) and the European Institute of Innovation and Technology (EIT).

${ }_{20}$ This is something that is often overlooked, including by Griller and Orator when they discuss the strengthening of political control (by the Commission) over agencies, compare infra.
} 
The last type is the true 'regulatory' or rule-making agency holding discretionary power to translate broad legislative guidelines into concrete instruments.

Most of the EU regulatory agencies belong to the first and second category. The most interesting EU agencies fall into the third category, whereas the Union legislator has not (yet) founded agencies that can truly be categorized as regulatory agencies.

\section{THE POLITICS OF ESTABLISHING AGENCIES}

Chiti notes that despite the many differences between the various establishing regulations, the agencification process has consolidated a more or less uniform organizational framework. He sees this uniformity in the way all European agencies have a double purpose: not only do they institutionalize co-operation and integration among the Member States' administrations and between the latter and the Commission; they also give a number of EU policy fields a certain decentralized order, in the centre of which we find a body that is external to the Commission, but nonetheless partly subject to its influence. ${ }^{21}$ The notion of agencies as a form of decentralized governance is frequently made, also by the Commission, ${ }^{22}$ but as Scott points out, ${ }^{23}$ there is hardly anything decentralized about the agencies apart from the fact that they are not geographically located in Brussels. This is quite clear when tracing the origin of the powers entrusted to the agencies. Most of these powers are not delegated by the Commission or any other EU institution but were previously exercised at the national level. Therefore, agencification actually comes down to centralization.

\footnotetext{
${ }^{21}$ Chiti, 'An important part of the EU's institutional machinery: features, problems and perspectives of European agencies', 46 Common Market Law Review 5 (2009), p. 1396-1398.

${ }^{22}$ Communication from the Commission, The operating framework for the European Regulatory Agencies, COM (2002) 718 final, p. 2.

${ }^{23}$ Scott, 'Agencies for European Regulatory Governance: A Regimes Approach' in D. Geradin, R. Munoz \& N. Petit (eds.), Regulation Through Agencies In The Eu, (Elgar, Cheltenham 2005), p. 70-71.
} 
Chiti correctly, however, notes that agencies perform a double purpose and constitute a compromise between the Commission and the Member States. The role of the Commission is especially important, since it was and will remain responsible for making any proposals to establish new agencies. Keleman's narration on the establishment of the European Food Safety Agency (EFSA) is quite revealing in this regard. ${ }^{24}$ The Commission's basic principle is the continuous aggrandizement of powers at the European level, in other words, a Europeanization of powers. This is preferably accomplished 'in house', through the aggrandizement of the Commission's powers. In general the Member States are reluctant to give new and more powers to the Commission. Therefore, if further integration cannot be achieved in the Commission's preferred way, it opts for a further Europeanization of powers through the establishment of agencies. Here is where the game of forces, alluded to by Chiti, unfolds further. ${ }^{25}$ The Member States are much more enthusiastic about giving powers to an agency than to the Commission: not only do they have representatives in the Boards of the agencies, the Boards also play a vital role in the appointment of the presidents of the agencies. Agencies are also geographically dispersed, meaning the seat of an agency is an attractive trophy to national leaders and therefore often the subject of lengthy negotiation. ${ }^{26}$

\footnotetext{
${ }^{24}$ Keleman explains how the development of the EU's competence in food safety has been tied to the BSE crisis. When the BSE crisis first broke out in the beginning of the 1990s in the UK, the Commission seized the opportunity to expand its regulatory capacity by establishing the Office of Veterinary and Phytosanitary Inspection and Control (OVPIC) in DG Agriculture. By 1995 this office faced human and financial resources problems. The Commission proposed to transform the office into an independent agency, so that adequate resources could be allocated. When the BSE crisis truly exploded in 1996, this created a window of opportunity for the Commission. Backed up by the European Parliament, the Commission proposed an internal reform expanding the OVPIC, withdrawing its proposal to create an agency. The idea behind this turnaround was that only the Commission itself would be a sufficient guarantee for independence, whereas an agency would be too vulnerable to 'capture' by the Member States. However, in 1999 corruption scandals put the Santer Commission under serious pressure, ultimately forcing it to resign. This closed the Commission's window of opportunity again: the Commission was no longer a guarantee for sound, independent policy. In 2000 the Commission again presented a proposal for a regulation establishing a food safety agency. See Keleman, 'The Politics of 'Eurocratic' Structure and the New European Agencies', 25 West European Politics 4 (2002), p. 105-108.

${ }^{25}$ Chiti, 46 Common Market Law Review 5 (2009), p. 1398.

${ }^{26}$ See for instance the negotiations on the seat of the EFSA in Vos, 'Agencies and the European Union', in L. Verhey \& T. Zwart (eds.) Agencies in European and comparative perspective, (Intersentia, Antwerp 2003), p. $126-127$
} 
Through the establishment of agencies, the Commission achieves further integration, albeit through a second-best approach. It is an approach that also entails certain risks, as former President of the Commission, Romano Prodi, made clear during a speech at the time of the IGC in 2000, where some Member States wanted to amend the Treaties to facilitate the establishment of agencies. Prodi warned that such fragmentation undermines the Community method by creating conflicting centres of powers. ${ }^{27}$ Therefore just as the Member States are wary of too powerful a Commission, so the Commission itself is wary of too powerful agencies. This is why the Commission is very keen to refer in its policy documents on the functioning of the agencies to the Meroni ruling. Applying a strict reading of the Meroni ruling to the agencies is part of the Commission's policy of keeping a check on the powers of the agencies. This reasoning has proven quite successful and a number of authors have adopted it without much question. In general, however, the Commission is in something of a quandary in its balancing act between keeping a check on agencies - in other words, controlling them -- but in the meantime reassuring the Member States that it does not dominate the agencies. This again is an important reason as to why the Commission wrongfully speaks about decentralisation through agencification (see supra). As already pointed out, sometimes further integration is only possible through agencies because agencies are perceived as distinct from the Commission. This is why the Commission describes agencies as satellites: ${ }^{28}$ they are separate, yet not wholly independent entities from the main body since to make them completely independent would open the door to bureaucratic competition. This is the Commission's delicate equilibrium exercise.

\footnotetext{
27 Speech by R. Prodi before the European Parliament, 3 October 2000, SPEECH/00/352, electronically available at < http://europa.eu/rapid/pressReleasesAction.do?reference=SPEECH/00/352 > (last visited 22.10.2010).

${ }^{28}$ European Commission, EU Agencies: Whatever you do, we work for you (Office for Official Publications of the European Communities, 2007), p. 1.
} 
These general political considerations are also translated in the internal organization and functioning of agencies. An in-depth exposé of the different arrangements for each agency falls outside the purpose of this article, but it is important to keep in mind that each time a new agency is being established, this is preceded by a political battle between the Member States in the Council, the Commission and, in recent years, the European Parliament. The ad hoc way of creating agencies and the political struggle during the decision-making process have resulted in the plethora of agencies, the internal organization of which, although built on a typical three part structure, ${ }^{29}$ is never the same for any two different agencies. More concretely, the representation in the boards and the selection and nomination of the director are major subjects of debate in the decision-making leading to the establishment of an agency, the outcome of which greatly determines the influence of the respective principals over the newly established agency. ${ }^{30}$

Therefore, when Chiti speaks of 'a rather uniform organizational framework' ${ }^{31}$ this must be understood as referring to the political reality in the relationship of the agencies with the Treaty Institutions and the national administrations, a reality that seems to confirm the neofunctionalist theory of power games between the Commission and the Member States. Nevertheless, a uniform legal framework is missing; hence the Commission's proposals to establish one (see infra). These proposals also entailed a uniformization of the internal organization of the agencies.

\section{§3. THE MERONI RULING}

\footnotetext{
${ }^{29}$ This three part structure consists of a policy making organ, the Board, an executive body, the Director and a specialized organ, incarnating the actual expertise of the agency.

${ }^{30}$ Typically the boards are dominated by the representatives of the Member States. It is only in the boards of three agencies (the European Food Safety Agency, the European Institute for Gender Equality and the Agency for Cooperation of Energy Regulators) that not every Member State has its own representative.

${ }^{31}$ Chiti, 46 Common Market Law Review 5 (2009), p. 1396.
} 
One of the main subjects of debate on agencies is the possibility of delegating powers to them. Is there any possibility to create these institutions and transfer powers to them? Most authors look to the ancient Meroni ruling of the Court of Justice to find an answer to this question.

In the Meroni case, the applicant company challenged the way the High Authority had organized the financial arrangements of the ferrous scrap regime. Meroni not only argued that the decision requiring it to pay a sum of money to the Imported Ferrous Scrap Equalization Fund was unlawful because of the infringement of an essential procedural requirement and the failure to state reasons but, more fundamentally, it also questioned the underlying general decision in which the High Authority delegated the powers for the financial operation of the regime to two bodies under Belgian private law, the so-called Brussels Agencies. ${ }^{32}$ Meroni essentially argued that, according to Article 8 of the ECSC Treaty, the High Authority was held 'to ensure that the objectives set out in this Treaty are attained in accordance with the provisions thereof' and that this did not leave any possibility for the High Authority to delegate its powers.

However, in its judgment, the Court did not exclude the possibility of entrusting certain tasks to bodies established under private law. After the Court had laid down the general possibility to delegate it proceeded to narrow that possibility down substantially. It referred to the general objectives of the Treaty as listed in Article 3 ECSC and noted that it is not certain that they could all be simultaneously pursued in all circumstances and that reconciling these objectives in individual cases requires genuine discretionary power. The Court proceeded by drawing attention to the provision in Article 3 ECSC that precedes the different objectives and in

\footnotetext{
${ }^{32}$ These were officially named Office Commun des Consommateurs de Feraille and Caisse de Péréquation des Ferailles importées.
} 
which it is stated that the institutions of the Community shall aim to achieve the objectives 'within the framework of their respective powers and responsibilities and in the common interest'. This balance of powers was, according to the Court, characteristic of the institutional structure of the Community and was no less than a 'fundamental guarantee granted by the Treaty, in particular to the undertakings and associations of undertakings to which it applies'. This guarantee would become ineffective if discretionary powers were to be entrusted to bodies other than those established by the Treaty. The Court thus concluded that the High Authority could not confer upon the authority to which powers are delegated, powers different from those it has itself received under the Treaty. The exercise of the powers entrusted to the body to which the powers are delegated must be subject to the same conditions as those to which it would have been subject if the High Authority had exercised them directly, particularly as regards the requirements to state reasons and to publish; and even when entitled to delegate its powers, the High Authority has to take an express decision transferring them and the delegation may relate only to clearly defined executive, but not discretionary powers.

\section{§4. APPLYING MERONI TO THE EU AGENCIES}

This ruling by the Court remained largely obscure for the decades to come but, as the academic interest in agencies was sparked by the second wave of agency-creation in the 1990s, so the interest in this ruling grew. Lenaerts was one of the first to frame the agencification process at EU level by referring to the Meroni ruling. ${ }^{33}$ He referred to the ruling when discussing the possibility of delegating powers to an internal body and explicitly

\footnotetext{
${ }^{33}$ Lenaerts, 'Regulating the Regulatory Process: Delegation of Powers in the European Community', 18 European Law Review 1 (1993), p. 23-49. In 1967 Maas already deplored, in general terms since no agency existed yet, the strict conditions imposed by the Court and the effects on the further institutional development of the Community. See Maas, 'Delegatie van bevoegdheden in de Europese Gemeenschappen', 15 Tijdschrift voor Europees en economisch recht (1967), p. 17.
} 
discussed the transposability of this judgment, based on the ECSC Treaty, to the EEC Treaty. These are two important elements that were also taken up by other authors in later contributions. While the latter was subject to serious academic debate, it is argued that the academic debate should focus more on the first of those presumptions, even more so given that the question on the transposability to the EC Treaty seems to have been solved by the Court in its case law. Some authors argued that in the context of the ECSC Treaty, a traité loi, the High Authority was endowed with important and detailed regulatory and implementing powers. The EEC Treaty, however, was a traité cadre with broad objectives to be achieved progressively and where the implementation powers mainly lay with the national administrations. Endowing European Agencies with powers would then not amount to a delegation of powers from a Union institution to that agency but would in fact come down to an extraction of powers from the national level, hence the Meroni ruling would have no bearing. ${ }^{34}$

\section{A. FROM ECSC TO EU}

Craig, Griller and Orator note that in a couple of recent judgments the Court of Justice has referred to the Meroni ruling. This would indeed confirm the transposability already identified by Lenaerts in 1993. In 2005, two of these rulings were made by the CJEU. In Tralli the Court applied the Meroni doctrine to an internal delegation within the ECB, whereby the Governing Council of the ECB delegated the power to adopt and amend the rules implementing the Conditions of Employment to the Executive Board. ${ }^{35}$ In Alliance for Natural Health the Court applied the Meroni condition of strictly executive powers to the delegation of implementing

\footnotetext{
${ }^{34}$ Dehousse, 'Misfits: EU Law and the Transformation of European Governance', Jean Monnet Working Paper No. 2 (2002), www.jeanmonnetprogram.org/papers/02/020201.html (last visited 30.10.2010); Geradin, 'The Development of European Regulatory Agencies: What the EU should learn from the American experience', 11 Columbia Journal of European Law 1 (2004), p. 10.

${ }^{35}$ Case C-301/02 P Carmine Salvatore Tralli v. ECB [2005] ECR I-4071.
} 
powers from the Community legislator to the Commission. ${ }^{36}$ Not only did the Court transpose the Meroni doctrine to the EC Treaty it also broadened the scope of the doctrine. The latter is generally overlooked by legal authors but it is important to consider that the bodies to which powers were delegated in the Meroni case were bodies established under private law and which fell completely outside the Community structure. In Tralli and Alliance for Natural Health the Court applied (parts of) the Meroni doctrine on the delegation of powers from one Treaty institution to another and to delegation wholly within a Treaty institution. These situations are of course totally different from a legal point of view compared to the facts of the case in Meroni.

\section{B. MERONI AND THE INSTITUTIONAL BALANCE}

The Court itself however has not (yet) explicitly applied the Meroni doctrine to the functioning of the Union agencies. This has been done in academic writing following the example of Lenaerts. Yet the state of play of EU agencies has changed quite dramatically since 1993. The majority of the agencies postdate 1993 and some of these recent agencies have been endowed with far more extensive powers than were held by the agencies in 1993 . Nevertheless, a lot of legal authors apply the Meroni doctrine to the current agencies and try to reconcile the current state of play with the doctrine. The main obstacle identified in legal literature to the further development of EU agencies is the principle of institutional balance derived from the Meroni ruling. ${ }^{37}$ Vos even states that the objection to agencies read into the Meroni case can be reduced to a single objection: distortion of the institutional balance. As

\footnotetext{
${ }^{36}$ Joined cases C-154/04 \& C-155/04, The Queen, on the application of Alliance for Natural Health and Others v. Secretary of State for Health and National Assembly for Wales [2005] ECR I-6451.

${ }^{37}$ See Van Ooik, 'The Growing Importance of Agencies in the EU' in D., M., Curtin \& R., A., Wessel (eds.) Good Governance and the European Union: reflection on concepts, institutions and substance, (Intersentia, Antwerp 2005), p. 125-152; Vos 'Agencies and the European Union', in L. Verhey \& T. Zwart (eds.) Agencies in European and comparative perspective, (Intersentia, Antwerp 2003); Griller \& Orator, 35 European Law Review 1 (2010), p. 3-35; P. Craig, EU Administrative Law, (Oxford University Press, Oxford 2006), p. 143-190; Majone 'Delegation of regulatory powers in a mixed polity', 8 European Law review 3 (2002), p. 319-339.
} 
the Treaty legislator has distributed powers among different institutions, these institutions need to exercise their powers with due regard for the powers of the other institutions. A delegation of discretionary powers to EU agencies would then upset this balance. ${ }^{38}$

As stated, paying the necessary respect to the principle of institutional balance puts a serious restraint on further agencification. This is why different authors have also looked into different ways of reconciling current but also future agencification with the principle. This is not an easy task, as some of their more recent EU agencies hold considerable powers. So much so that it has led several authors to conclude that only lip service is being paid to the Meroni doctrine and that in reality some EU agencies already operate in clear contravention of that doctrine. ${ }^{39}$ Vos argues that the institutional balance will not be upset so long as shifts of power are accompanied by reinforcing or re-balancing the existing institutions. She does not, however, elaborate on how to achieve this. Instead, she focuses more extensively on the need for a more modern view on administrative law. It is indeed the second of these observations that carries the most weight: there is an urgent and practical need for a modern administrative practice.

Although 'balance' is a dynamic concept, it is hard to come up with ways to 'rebalance' the institutional balance after a shift in power, especially because the concept itself incarnates $a$ zero sum conception of power. Griller and Orator on the other hand, do suggest ways of adjusting the institutional balance after such a shift in power. ${ }^{40}$ Their proposal is based largely on the strengthening of control mechanisms. These should secure the prerogatives of the

\footnotetext{
38 Vos 'Agencies and the European Union', in L. Verhey \& T. Zwart (eds.) Agencies in European and comparative perspective, (Intersentia, Antwerp 2003) p. 131.

${ }^{39}$ Majone, 'The Credibility Crisis of Community Regulation', 38 Journal of Common Market Studies 2 (2000) 289; Hofmann and Türk, 'Implementing Policy', in H. C. H. Hofmann and A. H. Türk (eds.), EU administrative governance, (Elgar, Cheltenham 2006), p. 89; Trondal, An Emergent European Executive Order, p. 164

${ }^{40}$ Griller \& Orator, 35 European Law Review 1 (2010), p. 27-30.
} 
legislature to take the political decisions and secure the position of the Commission as the main EU institution responsible for the implementation of EU law. Such control mechanisms would, according to Griller and Orator, enable the agencies to wield discretionary powers while keeping in step with the Meroni doctrine. Through these proposals, Griller and Orator try to address the issue of institutional balance, which they derive from the Meroni ruling. Apart from the question of whether it is correct to do so, a question which will be addressed later, it is important to note that by concentrating on ways to resolve the issue of institutional balance, they have lost sight of an important affirmation of the Court in Meroni, namely that '[a] delegation of powers ... which implies a wide margin of discretion ... cannot be considered as compatible with the requirements of the Treaty. ${ }^{41}$ The Meroni doctrine thus simply precludes the possibility to delegate discretionary powers, which makes it hard to see how Griller and Orator, in their endeavour to apply the Meroni ruling to agencies and according at the same time discretionary powers to these agencies, can ever be successful.

Apart from this legal issue, there are some practical issues undermining their proposals. If more control mechanisms are to be created and more control given to the other institutions, these institutions would also need the necessary expertise to exercise de facto control. If not, the newly created control mechanisms would merely result in an empty de iure control. However, if the in-house expertise of the Commission matches that of the agency, a necessary condition for effective control, this would call into question the raison d'être of agencies, in other words, the initial absence of expertise within the Commission or at European level. More control would also pose a threat to another important argument often cited in the defence of agencies: their independence from politics. Giving a veto right to the Commission

\footnotetext{
${ }^{41}$ Case 9/56 Meroni \& Co, Industrie Metallurgiche SpA v. High Authority [1958] ECR 154.
} 
over agency decisions, as Griller and Orator propose, could have very drastic and possibly dangerous effects on the independence of these agencies.

Finally, Van Ooik sees three main options for keeping the agencification process going without violating the principle of institutional balance: ${ }^{42}$ agencies could be endowed with a strict mandate, excluding the delegation of discretionary powers, which is, according to van Ooik, the case for agencies such as the Office for Harmonisation of the Internal Market (OHIM). Secondly, the agencies' tasks could be confined to information gathering and processing, that is to say, only establishing 'ordinary' agencies of the first category. Thirdly, the institutional balance itself could be redefined by a Treaty amendment. Unlike Vos, Van Ooik sees no possibility to delegate true discretionary powers to the agencies without a Treaty change enabling this. Also according to Van Ooik, an effective system of supervision and control could mitigate objections against a far-reaching delegation of powers, an option which has been explored by Griller and Orator (compare supra).

\section{CURRENT AGENCY PRACTICE AND INSTITUTIONAL BALANCE}

Before discussing the issue of the institutional balance, it is important to take a closer look at the criticism that the Meroni doctrine is already violated in the current agency practice. Indeed, assuming that the Meroni doctrine is applicable to the agencies, this would seem to be the case. The dominant line of reasoning in legal doctrine and the discourse of the Commission in its communications on agencies prescribe that for certain clearly specified

\footnotetext{
${ }^{42}$ Van Ooik, 'The Growing Importance of Agencies in the EU', in D., M., Curtin \& R., A., Wessel (eds.) Good Governance and the European Union: reflection on concepts, institutions and substance, (Intersentia , Antwerp 2005), p. 150-152.
} 
tasks, agencies may be allowed to participate in exercising executive function. ${ }^{43}$ This logic is apparent in Van Ooik's reasoning on the compatibility of the powers of the OHIM with the Meroni doctrine. However, Van Ooik's argument is not convincing. The Court in Meroni prohibited the delegation of discretionary powers and, although the OHIM has a strict mandate, this is not the same as saying it only exercises executive powers. The OHIM's strict mandate is obvious: it is the Union's trademark registration office and as such deals with applications from companies; it examines these applications on the basis of criteria laid down in the founding regulation and subsequently makes a decision which is binding on the applicant. A strict mandate does not however exclude the possibility of wielding extensive powers within the limits of this mandate. This becomes even more obvious when one takes a look at the European Aviation Safety Agency (EASA), one of the more recent agencies. Not only does it hold comparable powers to the OHIM and the Community Plant Variety Office (CPVO) since it takes an individual binding decision on whether or not to grant a certificate to an undertaking for a specific aviation product, it also holds more far reaching powers than the OHIM and CPVO. According to Article 18 of its founding regulation, ${ }^{44}$ the EASA also publishes certification specifications and guidance material for the industry. Riedel points out that these specifications, although de iure non-binding, are de facto binding on the undertakings, because only by following the guidelines of the EASA can they have reasonable certainty that their products will also be certified by the EASA. ${ }^{45}$ It might be said, therefore, that the EASA has a strict mandate since there are only so many well-defined tasks the EASA may undertake, but within these tasks the EASA has considerable powers, so much so that

\footnotetext{
${ }^{43}$ Communication from the Commission, The operating framework for the European Regulatory Agencies, COM (2002) 718 final, p. 6.

${ }^{44}$ Regulation (EC) 216/2008, [2008] O.J. L79/1.

${ }_{45}$ Riedel, 'Die EASA - Eine Einführung' (2006), electronically available at www.danielriedel.net/easa frankfurt.pdf (last visited 30.10.2010), p. 11-12.
} 
one might qualify the EASA as a quasi regulatory agency. ${ }^{46}$ What is more, the de iure, nonbinding nature of the certification specifications means that few legal remedies are available to the undertaking wishing to challenge these guidelines of the EASA. As is argued later, it is this kind of problem that was central to the Meroni ruling and doctrine.

Not only has agency practice already overstepped the limits set by the Meroni doctrine, the Court already seems to have endorsed this in its case law. In the Schräder case the applicant had applied to the CPVO for a Community plant variety right. ${ }^{47}$ The CPVO rejected this application because of a lack of distinctiveness of the candidate variety and this decision was later endorsed by the CPVO's Board of Appeal. The applicant then brought an action before the General Court to have the rejection decision of the Board of Appeal annulled. In its ruling, before assessing the pleas of the applicant, the Court first determined the scope of its powers of judicial review. This is where there are a number of remarkable elements in the Court's assessment. First, the Court seems oblivious to the fact that it is dealing with a decision of the CPVO, an agency. Instead the Court notes the wide margin of discretion a Community authority enjoys whenever it has to make a complex assessment in the performance of its duties. This again shows that endowing an agency with a strict mandate does not exclude the possibility of the agency wielding discretionary powers while fulfilling that mandate. One could of course argue that, although the Court seems to grant a wide margin of discretion to the CPVO in the exercise of its duties, this wide margin of discretion is not the same as the exercise of discretionary powers, which is needed to reconcile the different objectives of the Treaty, as envisaged in the Meroni ruling. After all, as Schneider notes, distinction can be

\footnotetext{
${ }^{46}$ In addition to the issuing of certification specifications, the EASA also assists the Commission in the implementation of the regulation by giving advice and preparing such implementation measures. Again, the Commission is de iure not bound by the advice of the EASA, but the information asymmetry is obviously in favour of the latter. Therefore the remark on the rubberstamping by the Commission of advice given by predecision making agencies may be made here as well.

${ }^{47}$ Case T-187/06 Schräder v. CPVO [2008] ECR 3151.
} 
made between legislative discretion and administrative discretion to adopt context adequate decisions. ${ }^{48}$ However, the second remarkable element of the Court's assessment is that it looks at the CPVO as the Community administration, justifying its limited judicial review by referring to previous case law on the genuine discretionary powers of the Commission in the Common Agricultural Policy and in its state aid control competence. ${ }^{49}$ In Schräder the Court even goes on to say '[h]owever, while the Community Courts recognise that the administration has a margin of appreciation in economic or technical matters that does not mean that they must decline to review the Commission's [sic] interpretation of economic or technical data. ${ }^{50}$ Thus, the Court recognized and endorsed the discretionary powers of the CPVO and did so by referring to the wide margin of discretion the Community administration may have. The Court did so without making any further distinction, within the administration itself, between the Commission and the agencies. In the case on appeal before the Court of Justice, this was examined further only by the Advocate General (AG), who endorsed the reasoning of the General Court. ${ }^{51}$

\section{BACK TO THE ROOTS: THE INSTITUTIONAL BALANCE IN MERONI}

It is clear that most authors see the principle of institutional balance as the main constraint on any evolution towards true regulatory agencies. Craig rightly observes that before tackling this legal problem, one should first reanalyze the rationale behind agency creation. As mentioned, numerous authors have pointed to the different merits of agencies to justify their existence and proliferation. But these are the merits of agencies vested with limited powers;

\footnotetext{
${ }^{48}$ Schneider, 'A common framework for decentralized EU agencies and the Meroni Doctrine', 61 Administrative Law Review (2009), p. 38.

${ }^{49}$ Case T-187/06 Schräder v. CPVO [2008] ECR 3151, para. 59.

${ }^{50}$ Ibid., para. 61.

${ }^{51}$ Opinion of Advocate General Mazák's in case C-38/09 P Schräder v. CPVO, Judgment of 15 April 2010, not yet reported.
} 
true regulatory agencies hold more extensive powers, which must of course be justified on other grounds. I argue that, even considering Craig's observation, the principle of institutional balance that is central to the debate on delegation of powers to EU agencies and which many authors derive from the Meroni ruling cannot be derived automatically from that ruling. The main objection to this is that the principle of institutional balance was introduced, elaborated and refined by the Court in its case law. The principle as it is construed today is not the same as it was construed in the time of the Meroni ruling. However, most authors apply the modern interpretation of the principle in their analyses of the Meroni ruling and its consequences for contemporary agencies. Important to note is that at the time of the Meroni ruling, the Court did not even use the concept of institutional balance, as this was introduced only years later. ${ }^{52}$ The Meroni judgment then only forms part of the different constituent elements of this principle as it evolved later in the case law of the Court. ${ }^{53}$ It is not self-evident, therefore, to apply the principle in its evolved interpretation to make sense of the Meroni judgment, as Vos would have us do when she explicitly refers to the institutional balance as applied by the Court in the Chernobyl case of $1990 .{ }^{54}$ Other authors do not explicitly refer to more recent case law on the institutional balance but do apply it implicitly.

The main objection to applying the modern interpretation of the principle of institutional balance is that in its evolution from 'balance of powers' in Meroni to the modern day 'institutional balance', a qualitative leap has occurred. As Jacqué points out, the principle of institutional balance and in Meroni the balance of powers was originally conceived as a substitute for the principle of the separation of powers of Montesquieu, the aim of which was

\footnotetext{
${ }^{52}$ See Case 25/70 Köster [1970] ECR 1161.

${ }^{53}$ Lenaerts \& Verhoeven, 'Institutional Balance and Democracy' in C. Joerges en R. Dehousse (eds.), Good Governance in Europe's integrated market, (Oxford University Press, Oxford 2001) p. 44-45.

54 Vos 'Agencies and the European Union', in L. Verhey \& T. Zwart (eds.) Agencies in European and comparative perspective, (Intersentia, Antwerp 2003) p. 131; Case C-70/88 European Parliament v. Council of the European Communities [1990] ECR I-2041.
} 
to protect individuals against the abuse of power. ${ }^{55}$ By upholding the balance of powers, the Court safeguarded not only the decision making process envisaged by the Treaties but ultimately also the accompanying guarantees for private individuals. Jacqué observes that this protective aspect of the principle seems gradually to have been lost as other means of protection appeared. This radically changes the way the Meroni ruling ought to be interpreted, and, as is explained later, even more so for agencies specifically. To understand the underlying logic of the Meroni ruling, it is interesting to read the Opinion of Advocate General Roemer in the case. ${ }^{56}$ The AG first remarks that in a modern constitutional state, two important conditions should apply to the delegation of powers to bodies under private law. In the first place, the delegation may only be done by law which accurately describes the content of the delegation and, in the next place, sufficient judicial protection against the acts of such organisations should be guaranteed. He then goes on to look at the specificity of the ECSC context and remarks that the Treaty does not explicitly provide for such delegation, neither does it prohibit it. What he foremost emphasizes is that, in the case of delegation, the regime of judicial protection as established by the Treaty should be upheld. This can be achieved, still according to AG Roemer, by equating the acts of these bodies with acts of the High Authority or by having the High Authority take the final decision.

The AG took a relaxed stance towards delegation and was foremost pre-occupied with the continued respect for the system of judicial protection. The possible solutions offered by the AG are a further indication of this. The same pre-occupation was furthermore also central to the ruling by the CJEU. However, in its ruling the Court did not choose the solution offered by the AG, that is to say, the equation of acts of private bodies with acts of the High Authority. Instead the Court tried to solve the issue at hand by prescribing that these bodies

\footnotetext{
${ }_{55}^{55}$ Jacqué, 'The Principle of Institutional Balance', 41 Common Market Law Review 2 (2004), p. 384.

${ }^{56}$ Opinion of Advocate General Roemer in Case 9/56 Meroni \& Co, Industrie Metallurgiche SpA v. High Authority [1958] ECR 89.
} 
may only exercise strictly executive powers. Apparently in its juxtaposition of executive and discretionary powers, the Court assumed that only the exercise of the latter could give rise to problems pertaining to the regime of judicial protection as established by the Treaty. This is not the case, however, as the Court would also implicitly recognize a year later in the SNUPAT case. ${ }^{57}$ In SNUPAT the Court equated a notification by the same 'Brussels Agencies' as in Meroni to an undertaking ordering it to pay a certain amount of money to the Fund, with a decision of the High Authority. If the Court had ruled differently, such a notification would not have been open to applications for annulment, thus depriving the undertaking concerned of the protection offered by Treaty.

Despite the different solutions worked out by the AG and the Court in Meroni, it must be clear that the key concern for both was the way in which rights of private parties, as guaranteed by the regime of judicial protection established by the Treaty, would still be guaranteed after certain tasks have been outsourced to private bodies outside the Treaty. This is of course something very different from the way the institutional balance is conceptualized today and should make clear that the relevance of Meroni for any delegation issue is its insistence on the obligation to respect the fundamental principle of the right to judicial protection. Ironically this is one of the problems in the current process of agencification, because of the ad hoc way in which the agencies have been established and the increasing powers conferred on them. Until the entry into effect of the Treaty of Lisbon, no mention was made of the agencies in the Treaties and a piecemeal system of judicial supervision was put in place through the establishing regulations of the agencies. ${ }^{58}$ What is more, the Union legislator has not developed this system in a consistent way across the different regulations,

\footnotetext{
${ }^{57}$ Joined cases 32/58 \& 33/58 Société Nouvelle des Usines de Pontlieue - Acieries du Temple v. High Authority [1959] ECR 127.

${ }_{58}^{5}$ See Saurer, 'Individualrechtsschutz gegen das Handeln der Europäischen Agenturen', 45 Europarecht 1 (2010), p. 51-66.
} 
resulting in a different regime depending on the agency concerned. More specific problematic issues of agencification from the perspective of legal protection are inter alia the fact that some EU agencies have the power to give de iure non-binding advice, which is de facto binding and the jurisdiction of the CJEU over decisions of the agencies of the former second and third pillar. ${ }^{59}$

\section{E. AGENCIES: OUTSIDE BODIES?}

Although the concern expressed in Meroni applies generally, it is still important to point out that the Meroni ruling concerned the possibility to delegate certain powers to bodies established under private law. This is another potential pitfall when looking at the EU agencies through the Meroni ruling. It is quite clear that the agencies are not established under private law but are public institutions founded by secondary legislation. Although in issues of delegation -- regardless of the nature of the body to which powers are entrusted -- the greatest solicitude should be given to maintaining clear lines of accountability, a different approach to the delegation issue is indeed justifiable depending on whether powers are entrusted to public or private bodies. Consequently, the references the Court made to the Meroni ruling in the above mentioned recent judgments dealing with inter-institutional and intra-institutional delegation should be seen as quite unfortunate.

Instead a modern view of administration is necessary, allowing for flexible solutions such as establishing agencies and this is recognized by authors such as Vos. ${ }^{60}$ However, extending the scope of Meroni and applying it to agencies and private bodies alike is incompatible with such a modern view. Such an interpretation of Meroni does not allow for flexibility because it only distinguishes between Treaty institutions, on the one hand, and non-Treaty institutions on the

\footnotetext{
${ }^{59}$ Ibid., p. 61-64.

${ }^{60}$ Vos 'Agencies and the European Union', in L. Verhey \& T. Zwart (eds.) Agencies in European and comparative perspective, (Intersentia, Antwerp 2003), p. 132.
} 
other, thus making it impossible to delegate significant tasks to agencies, despite the fact that they are fundamentally different from private bodies. The assertion that Meroni applies to Union Administration therefore does not sit well with a modern view on administration and, rather, amounts to conflation, since Meroni only dealt with delegation of powers to bodies established under private law. Hartley's discussion on delegation exemplifies this. He distinguishes four types of delegation: delegation to the Commission, delegation to the Member States, delegation within an institution and delegation to outside bodies. ${ }^{61}$ It does not make much sense then to classify the EU agencies as outside bodies.

These are a number of issues that have received little or no attention in legal doctrine. Although Griller and Orator claim Meroni remains good law, ${ }^{62}$ it cannot simply be assumed to frame the process of agencification. In Meroni the Court ruled on a delegation to bodies established under private law, but the fact that the EU agencies are public bodies warrants a more generous stance towards delegation of powers to EU agencies. Furthermore it was not the institutional balance of the Chernobyl case (compare supra) but the concern for the Treaty's system of judicial protection that was central to the Court's reasoning in Meroni and if the Meroni ruling is to be a guide in the process of agencification, this general concern should be honoured. Lastly, from a practical point of view, to apply a strict and untailored reading of Meroni to the EU agencies makes no sense either as a number of EU agencies already dispose of discretionary powers. This is completely ignored by the European Commission in its proposal for an EU agency framework, as is shown in the following and final section.

\footnotetext{
${ }^{61}$ T. C. Hartley, The Foundations of European community law: an introduction to the constitutional and administrative law of the European community, (Oxford University Press, Oxford 2003), p. 118-124.

${ }^{62}$ Griller \& Orator, 35 European Law Review 1 (2010), p. 21.
} 


\section{§5. THE COMMISSION PROPOSAL FOR AN INTERINSTITUTIONAL AGREEMENT AND FOLLOW UP}

After having highlighted these contentious issues, it is interesting to take a look at how the EU institutions themselves are trying to address the issue of agencification, but also how they interpret the Meroni judgment and what the implications would be for the current debate between the institutions in the light of Meroni re-read.

As mentioned above, a legal framework for the EU agencies does not yet exist. This is still a subject of debate amongst the EU institutions and the Member States and already goes back quite some time. Vos notes that there was serious discussion during the IGC leading to the Nice Treaty on a possible amendment to the Treaties to provide for the possibility to establish agencies. Several proposals were made to this end. However, particularly because of reservations on the part of the Commission, none of these proposed amendments made it in the Nice Treaty and the matter remained unresolved. In 2001, in its White Paper on European Governance, the Commission announced that it would define the criteria for the creation of new agencies and the framework in which they operate by $2002 .{ }^{63}$ A year later the Commission announced that it would submit a proposal for an interinstitutional agreement to the Council and Parliament, setting out the conditions for the creation of regulatory agencies. $^{64}$

The Commission's announced draft institutional agreement was only submitted to the Council and Parliament in 2005. The most perplexing thing was that the third wave of agency creation had already taken its full course: by then the Commission and the rest of the Union legislature

\footnotetext{
${ }^{63}$ European Governance: A White Paper, COM (2001) 428, p. 24.

${ }^{64}$ Communication from the Commission, European Governance: Better lawmaking, COM (2002) 275, p. 5.
} 
knowingly proposed and established new agencies in the absence of a clear framework. ${ }^{65}$ This does not quite seem in line with the notion of good governance, central to the Commission's White Paper of 2001.

\section{A. THE PROPOSED INTERINSTITUTIONAL AGREEMENT}

In its explanatory memorandum on its draft institutional agreement the Commission explains the need for a common framework: the lack of such a framework would result in an opaque situation, difficult for the public to understand and detrimental to legal certainty. ${ }^{66}$ The Commission then goes on to state the principles of good governance, according to which the proposed framework should be established. A re-read Meroni judgment would indeed have the Commission focus on the principles of transparency and (judicial) accountability. The Commission, taking the principles of good governance as a starting point for its proposal, may also be interpreted in two ways: firstly, this is an obligation of result on the part of the Commission to ensure that its proposal fully achieves these principles; and it should be considered as the Commission's major motive for initiating this proposal. The above observation on the continuing establishment of agencies in the absence of a framework, already casts doubt on these premises.

Since the Commission's proposal stranded, it is not analyzed in detail here. Instead some main elements are considered. To begin with, the nature of an interinstitutional agreement, which at most may only bind the institutions that are party thereto, may in no way amend the Treaties. Moreover the Commission only envisaged the framework to be applied to future

\footnotetext{
${ }^{65}$ In total, 11 new (then EC) agencies have been established since the Commission White Paper on European Governance.

${ }^{66}$ Draft Interinstitutional Agreement on the operating framework for the European regulatory agencies, COM (2005) 59 final, p. 2.
} 
agencies, rather than all agencies. According to the Commission, applying the framework to future and existing agencies would be too difficult. ${ }^{67}$ As mentioned, this did not prevent the Commission and the Union legislature from establishing new agencies, to which the future framework would not apply, even after the Commission made its proposal for a framework. The scope of the draft agreement was also limited to the future first pillar agencies, excluding the second and third pillar agencies. This distinction does no longer make much sense following the entry into effect of the Lisbon Treaty. As Curtin notes, a horizontal approach should be followed encompassing the entire EU administration and not just the former EC administration. $^{68}$

As for the proposal itself, an impact assessment would precede the establishment of agencies. It would include several factors and would inter alia apply the principles of subsidiarity and proportionality. This is in response to a certain criticism of a number of agencies that are small or only have limited, supporting tasks: ${ }^{69}$ is their establishment justified in the light of these principles given the high fixed costs of establishing an agency?

Furthermore, the Commission proposed to establish future agencies using the legal basis of the policy in which they would be active, rather than the then Article 308 EC (now Article 352 TFEU). As the Commission acknowledged in its draft proposal, this new choice of legal basis was in fact already well established, since all the agencies of the third wave had been established in this way.

\footnotetext{
${ }^{67}$ Ibid., p. 3.

${ }^{68}$ Curtin, 'Delegation to EU Non-Majoritarian Agencies and the Emerging Practices of Public Accountability', in D. Geradin, R. Munoz \& N. Petit (eds.), Regulation Through Agencies In The EU, (Elgar, Cheltenham 2005), p. 113.

${ }^{69}$ Geradin and Petit, 'The Development of Agencies at EU and National Levels: Conceptual Analysis and Proposals for Reform', Jean Monnet Working Paper No. 1 (2004), electronically available at http://www.jeanmonnetprogram.org/papers/04/040101.pdf (last visited 30.10.2010), p. 39-40.
} 
The Commission also devoted special attention to those agencies with the most intense prerogatives: that is to say, those agencies that apply Union standards to specific cases and are therefore given the power to adopt individual decisions that are legally binding on third parties. This touches the contentious issue of which powers may and, more importantly, may not be conferred to agencies. The Commission, referring to the Meroni ruling, therefore clarified that the following powers could not be entrusted to agencies: the power to adopt general regulatory measures, the power to arbitrate in conflicts between public interests or exercise political discretion and those powers conferred on the Commission by the Treaty. As was explained before concerning the quasi-regulatory powers entrusted to the EASA, the limits which the Commission seeks to impose, referring to Meroni, have already been exceeded. Thus the Commission's proposal concerning a framework for future agencies was already outdated in terms of current practice on this matter. What is more, by withholding the exercise of political discretion from agencies, the Commission assumes a clear distinction between technical and political issues. In reality this distinction is not clear at all, as Griller and Orator also point out. ${ }^{70}$ The criterion applied by the Commission is not just outdated, as it is doubtful whether there ever was a clear distinction between political and technical issues, but is probably also oversimplified. This is a serious shortcoming since the way this criterion is defined would determine which powers may or may not be entrusted to agencies.

The literal reading of Meroni applied by the Commission to future agencies is therefore not workable since the Commission does not elaborate the general concepts it uses to delimitate agency powers. It does not lead to the legal certainty the Commission sought with its proposal because it does not sufficiently clarify the limits that apply to conferral of powers to agencies, as current agency practice also shows. The Commission's reliance on Meroni seems therefore

\footnotetext{
${ }^{70}$ Griller \& Orator, 35 European Law Review 1 (2010), p. 22.
} 
foremost inspired by its aspiration to defend its powers against possible encroachment by the agencies. Instead of using the Meroni judgment to curtail the powers of agencies, a re-read Meroni judgment would have the Commission focus on the (judicial) control mechanisms applicable to agencies in their functioning and with this the necessary transparency for a meaningful accountability.

A real novelty in the draft of the Commission, however, was the proposed composition of the Boards of future agencies, which were also to be downsized. The Commission proposed the introduction of parity between the Council and the Commission with the possibility to allow representatives of interested parties to be members, albeit without voting right. Evidently this would be a major change from the current practice and would bring uniformity to the internal organization of the agencies. Concerning the appointment of the Director, the Commission proposed to consolidate and codify the evolution in practice: the Director would be appointed by the Board on the basis of a list of candidates proposed by the Commission. Before the official appointment, the candidate might be asked to answer questions and make a declaration before the competent committee(s) of the European Parliament. Although the procedure proposed by the Commission to appoint the Director was in itself not new, the altered composition of the Board would have given the Commission much more leverage in the appointment of the Director. It should be noted that the Commission's 2005 proposal deviates from its 2002 Communication on the operating framework for the European Regulatory Agencies. ${ }^{71}$ In the latter communication, the Commission foresaw that the Director would be appointed by the Commission on the basis of a list of candidates from the Board. ${ }^{72}$ This was abandoned in 2005, although the Commission did not indicate why. It may be that the Commission realized its proposals concerning the Board and the Director combined would

\footnotetext{
${ }^{71}$ Communication from the Commission, The operating framework for the European Regulatory Agencies, COM (2002) 718 final.

${ }^{72}$ Ibid., p. 10.
} 
have been too ambitious for the Member State as it would have shifted too much power towards the Commission, away from the Council and Member States.

\section{B. FOLLOW UP}

The Commission's draft institutional agreement was sent to the other institutions in February 2005. The Parliament responded positively with a resolution putting forward its position. ${ }^{73}$ The Parliament took a co-operative but critical stance. It expressed its concern on the continual growth of agencies at the European level and rightly observed that the future framework should gradually be applied to existing agencies as well as future agencies. However, in its resolution, the Parliament is completely oblivious to the constitutional issues concerned in the agencification process and more occupied with the extent of its control over the agencies. The Council was not very enthusiastic about the Commission's draft and, as a consequence, this is where the discussions foundered. The legal service of the Council doubted whether an interinstitutional agreement was the appropriate instrument for such a framework because it felt that the draft submitted by the Commission went beyond the establishment of arrangements for co-operation between the institutions. According to the Council, the legislature would be bound in the future by a procedure not laid down in the Treaties. ${ }^{74}$ Andoura and Timmerman note that, on a political level, the Council also viewed the Commission's draft as too ambitious and detailed, not leaving enough margin for negotiation. $^{75}$

\footnotetext{
${ }^{73}$ European Parliament resolution on the draft interinstitutional agreement presented by the Commission on the operating framework for the European regulatory agencies, OJ C 285 E/123 22 November 2006.

${ }^{74}$ Answer of Lord Bach (President-in-Office of the Council) to oral question O-0093/2005 by Jo Leinen and Janusz Lewandowski, on behalf of the AFCO Committee, to the Council on the Draft interinstitutional agreement on the operating framework for the European regulatory agencies.

${ }^{75}$ Andoura and Timmerman, 'Governance of the EU: The Reform Debate on European Agencies Reignited', EPIN Working Paper No. 19 (2008), electronically available at http://www.ceps.eu/files/book/1736.pdf (last visited 30.10.2010), p. 27.
} 
As a result the negotiations came to dead-lock and, in March 2008, the Commission announced it would withdraw its proposal for a draft interinstitutional agreement ${ }^{76}$ (it eventually formally did in March 2009). ${ }^{77}$ Furthermore, the Commission announced it would undertake an evaluation of the existing agencies and that it would not propose new agencies before this evaluation was concluded. ${ }^{78}$ The Commission's pledge to abstain itself from proposing new agencies did not, however, survive the financial and economic crisis. As Europe and the world were faced with the failures of financial supervision, the Commission proposed a European system of supervision, inter alia through the establishment of a number of agencies. ${ }^{79}$ In its 2008 communication, the Commission also invited the Council and Parliament to join it in a dialogue, organized in an inter-institutional working group, on the place of agencies in European governance. At the same time the Commission also made it clear that this would not mean the dialogue should be started from scratch as it would itself 'continue to use the philosophy and core principles of the proposed interinstitutional agreement as a point of reference for its own approach to agencies. ${ }^{80}$ Again the Parliament took a constructive stance in voting a resolution reiterating its point of view urging a swift commencement of the interinstitutional dialogue. ${ }^{81}$ Again the Council was more recalcitrant. However, unlike the Commission and the Parliament, the Council clearly indicated that the interinstitutional working group should also look into the role and position of the agencies in the EU's institutional landscape. ${ }^{82}$ Indeed it is only by answering this question that there can

\footnotetext{
${ }^{76}$ Communication from the Commission to the European Parliament and the Council, COM (2008) 135 final.

${ }^{77}$ Withdrawal of obsolete Commission proposals, OJ C 71/17, 25 March 2009.

${ }^{78}$ Communication from the Commission to the European Parliament and the Council, COM (2008) 135 final, p. 9.

${ }^{79}$ Proposal for a Regulation of the European Parliament and of the Council establishing a European Banking Authority, COM (2009) 501 final; Proposal for a Regulation of the European Parliament and of the Council establishing a European Insurance and Occupational Pensions Authority, COM (2009) 502 final; Proposal for a Regulation of the European Parliament and of the Council establishing a European Securities and Markets Authority, COM (2009) 503 final.

${ }^{80}$ Ibid.

${ }^{81}$ European Parliament resolution of 21 October 2008 on a strategy for the future settlement of the institutional aspects of Regulatory Agencies (2008/2103(INI)), OJ C 15 E/27, 21 January 2010.

${ }^{82}$ Council of the European Union, Approval of a reply to be sent to Mr José Manuel BARROSO, President of the European Commission, Brussels, 7 November 2008, 14948/08, p. 4.
} 
be clarity on the powers entrusted to these agencies and only by clarifying the limits that need to be respected in entrusting agencies with certain powers can there be a meaningful debate on the level of control and the type of control mechanisms that are necessary and appropriate.

Looking at the proposal and the preceding communications from the Commission, it is clear that the principles of good governance have influenced the philosophy of the Commission. However, it is equally clear that this philosophy and the endeavours to apply it to the (future) agencies is not a simple deduction from these principles. The Commission is not only trying to gain more control over the agencies but also tries to codify certain, albeit vague, limits to the powers that may be entrusted to them so as to keep agencies in check. In reality, the Commission's proposal consists for a large part in codifying existing agency practice but fails to address certain fundamental issues concerning the agencies. The Parliament for its part seems primarily concerned with its own powers over the functioning of the agencies, whereas only the Council has pointed to the need to include the primordial question on the position of the agencies in the institutional architecture of the Union in the debate. Likewise it is the institutional balance that seems to be a major concern for the Treaty institutions, their contributions to the debate being inspired by institutional self-interest as each of them seeks to extend (or maintain) its influence over the agencies and strengthen its position vis-à-vis the other Treaty institutions. However, as was noted, the balance of powers in Meroni, which touches upon the general interest, is different from the institutional balance, which may be seen as a balance between institution-specific interests.

A re-reading of the Meroni judgment would shift the focus away from the uneasy dichotomy between executive and discretionary powers and would re-emphasize the balance of powers instead of the institutional balance. This would have twofold consequences for the 
Commission's proposal. For one it would mean the Commission would have to make a bigger effort in setting out the limits to the possible conferral of powers to agencies, as it would no longer be able to hide behind the too simplistic distinction between executive and discretionary powers. More thorough thought by the Commission would ultimately touch upon the question of the nature of agencies and their place in the institutional architecture of the Union, a question that was left untouched by the Commission in its proposal. Secondly it would emphasize, even more than is now the case, the need for transparency in the functioning of agencies and, because of a clarified delimitation of powers, the question of accountability of both Commission and agencies would be addressed in a more satisfactory way, contributing to the realization of the principles of good governance.

\section{§6. CONCLUSION}

Although the Meroni ruling is often referred to in the debate on EU agencies, the relevance of Meroni for EU agencies should be researched more thoroughly. The question is not so much whether Meroni itself is good law but whether the many differences between the facts of the case and the context of Meroni and that of the current day EU agencies, can be so easily dismissed as is now being done. Additionally, whether it makes sense to apply what was originally the balance of powers of Meroni as the institutional balance of Chernobyl to the functioning of agencies is an important consideration.

It has been argued that the true relevance of the Meroni ruling for the current process of agencification is the concern of the Court to refer to the balance of powers: that the system of judicial protection offered by the Treaty should be upheld at all times. This is because the prerequisites of accountability in general should be upheld at all times, regardless of the 
delegator, delegatee or the form, content and scope of the delegation. The pre-requisite of accountability therefore supersedes the factual and contextual differences between Meroni and the current day agencies. However, this general accountability cannot be reduced to a purely judicial accountability, as expressed in Meroni, but also involves political accountability.

It is political accountability, more precisely political control, which so far has been central to the discussions at political level between Commission, Parliament and Council. Of those three, the Commission and the Parliament especially seem more concerned with their control over the agencies than with the constitutional positioning of the agencies while the former actually depends on latter. When the Commission refers to the Meroni ruling to interpret the position of the agencies, this seems foremost inspired by the desire of the Commission to stay 'on top' of the agencies. This is all the more apparent when the Commission tries to apply a strict reading of the Meroni doctrine on the future agencies, even though the functioning of the current agencies already is in contravention to such a strict reading. A re-reading of the Meroni judgment would help the Commission (re)focus the debate on those fundamental issues concerning agencification, that so far are too much neglected. 